\title{
Impact of Fertigation Levels and Different Types of Mulching on Growth and Yield of Guava (Psidium guajava L.) under Ultra-High Density Planting in Chhattisgarh Plains
}

\author{
Purnendra Kumar Sahu ${ }^{1 *}$, G. D. Sahu ${ }^{1}$ and Vedhika Sahu ${ }^{2}$ \\ ${ }^{1}$ Department of Fruit Science, ${ }^{2}$ Krishi Vigyan Kendra, Bemetara, \\ Indira Gandhi Krishi Vishwavidyalaya, Raipur (C.G.) 492012, India \\ *Corresponding author
}

Keywords

Guava, drip

irrigation,

fertigation,

mulching, ultra high

density planting, yield

Article Info

Accepted:

10 April 2020

Available Online:

10 May 2020

\section{A B S T R A C T}

A field experiment was conducted during the year 2017-18 and 2018-19 in mrig bahar crop at research field of Precision Farming Development Centre (PFDC), Department of Fruit Science, Indira Gandhi Krishi Vishwavidyalaya, Raipur (C.G.). The experiment was laid out in Factorial Randomized Block Design (FRBD) with three replications and nine treatments namely (Variety) Lalit, Allahabad safeda and L-49, (Fertigation levels) 60\% RDF, 80\% RDF and 100\% RDF and (Mulch levels) Natural mulch, Silver mulch and Without mulch. The objective to study the Effect of fertigation scheduling and different types of mulching on growth and yield of guava under ultra-high density planting. Results revealed that all the growth parameters like plant height, plant girth, plant spread and yield parameters like number of flowers per plant, number of fruits per plant and fruit yield per plant, fruit yield per hectare were recorded highest with Lalit variety, $80 \% \mathrm{RDF}$ and silver mulch and also found minimum in variety $\mathrm{L}-49,60 \%$ RDF and without mulch.

\section{Introduction}

Guava (Psidium guajava L.) is very popular fruit in India. It belongs to family "Myrtaceae" and an important commercial fruit crop of tropical and sub-tropical region of India. It is known as 'Apple of tropics' and rich in Ascorbic acid (Vitamin C) and pectin content besides being a good source of other vitamins and minerals.

Ultra high density planting or meadow orchard system is the fastest way of reducing the gestation period and simultaneously 
increasing the productivity of the orchards. Accommodation of the maximum number of precocious plants per unit area to get the maximum profit per unit of the tree volume without impairing the soil fertility status is called the high density planting.

The meadow orchard is a modern method of fruit cultivation using small or dwarf tree with modified canopy. Water stress during the critical stages of fruit growth and development is main reason for low productivity. For efficient water and weed management under such situation, drip irrigation along with mulching is the best option which saves $25-30 \%$ irrigation water.

Fertigation is a new concept gaining momentum in India. The nutrient consumption per hectare and fertilizer use efficiency is very low in India. The main reasons for the low efficiency are the type of fertilizer used and its method of application adopted by Indian farmers.

Farmers are using solid fertilizers for fruit crop production but these are not totally water soluble and hence, are less available to the plants. Hence, there is a need to develop a suitable method of application of fertilizer through drip system, which will improve the quality and quantity of fruit crop production.

Mulching plays an important role in soil moisture conservation, improving soil structure, regulates soil temperature and reduces weed growth (Reddy and Khan, 2000) water loss is reduced under plastic mulch. The soil under plastic mulch remains loose, friable and well-aerated.

Continuous use of organic mulches also improved the organic matter content of soil and better soil aeration (Borthakur and Bhattacharya, 1992). The encouraging results of mulching have been so far reported in fruit crops like banana.

\section{Materials and Methods}

Field experiment was carried out during the year 2017-18 and 2018-19 in mrig bahar crop at research field of Precision Farming Development Centre (PFDC), Department of Fruit Science, Indira Gandhi Krishi Vishwavidyalaya, Raipur (C.G.). The experiment was carried out with factorial randomized block design with 3 replication and 9 treatment compairising of three cultivars of guava [lalit, allahabad safeda and sardar (L-49)], three level of fertigations scheduled at $60 \%, 80 \%$ and $100 \%$ recommended dose of fertilizer per plant in

Accordingly, the estimated amount of $60 \%$, $80 \%$ and $100 \%$ of recommended doses of fertilizer was 385:555:250 gm N:P:K/plant and three levels of mulches (Natural mulch, Silver mulch and Without mulch) with twenty seven treatment combinations. The fertilizer was dissolved in a tank and irrigation was applied weekly as per treatments. The water requirement of the crop was computed on daily basis by using the following equation as suggested by Shukla et al., (2001).

$$
\mathrm{V}=\mathrm{Ep} . \mathrm{Kp} \cdot \mathrm{Kc} \cdot \mathrm{Sp} \cdot \mathrm{Sr} . \mathrm{Wp}
$$

Where,

$\mathrm{V}=$ Volume of water required (litre / day / plant)

$\mathrm{Ep}=$ Pan evaporation as measured by Class-A pan evaporimeter ( $\mathrm{mm} /$ day)

$\mathrm{Kc}=$ Crop co-efficient (co-efficient depends on crop growth stage)

$\mathrm{Kp}=$ Pan co-efficient

$\mathrm{Sp}=$ Plant to plant spacing $(\mathrm{m}) \mathrm{Sr}=$ Row to row spacing $(\mathrm{m})$

$\mathrm{Wp}=$ Fractional wetted area, which varies with different growth stage (0.3 to 1.0) The values of pan coefficient and crop coefficients were taken from (Doorenbos and Pruitt, 1977). 
The water requirement of guava crop was estimated on daily basis for all months considered under study. Daily time to operate drip irrigation system was worked out taking the application rate per plant.

Drip system was scheduled on alternate days; hence total quantity of water delivered was cumulative water requirement of two days. Observations on water requirement, growth character and yield of guava were recorded and analyzed statistically following the standard procedures (Panse and Sukhatme, 1985).

\section{Results and Discussion}

Observation recorded on the effect of fertigation levels and different types of mulch on growth (Table.1) and yield of guava is presented in Table no. 2. Among the various cultivars, variety, $\mathrm{V}_{1^{-}}$Lalit produced significantly maximum plant height (144.65 $\mathrm{cm}$ and $143.53 \mathrm{~cm})$, plant girth $(15.82 \mathrm{~cm}$ and $17.89 \mathrm{~cm})$ and plant spread $(165.62 \mathrm{~cm}$ and $173.78 \mathrm{~cm}$ ) in both the years respectively (2017-18 and 2018-19) and also on the basis of mean data $(144.09 \mathrm{~cm}, 16.86 \mathrm{~cm}$ and $169.70 \mathrm{~cm}$ ) and yield attributes like- number of flowers per plant (645.52 and 651.05), number of fruits per plant (261.32 and 266.28), fruit yield per plant $(9.93 \mathrm{~kg}$ and $12.77 \mathrm{~kg}$ ) and fruit yield (49.62 t/ha and 63.88 $\mathrm{t} / \mathrm{ha}$ ) in both the years respectively (2017-18 and 2018-19) and also on the basis of mean data $(648.29,263.80,49.62 \mathrm{~kg}$ and 56.75 t/ha).

The lowest values of growth and yield characters were recorded in variety $\mathrm{V}_{3}-\mathrm{L}-49$. These results are supported by the findings of earlier workers like Paikra et al., (2016) also noted that Lalit and Allahabad safeda of guava produced significantly maximum growth and yield attributes from the others.
The data recorded on the effect of different levels of fertigation indicates that maximum plant height $(137.84 \mathrm{~cm}$ and $147.12 \mathrm{~cm})$, plant girth $(15.95 \mathrm{~cm}$ and $17.50 \mathrm{~cm})$ and plant spread $(165.85 \mathrm{~cm}$ and $169.95 \mathrm{~cm})$ in both the years respectively (2017-18 and 2018-19) and also on the basis of mean data $(142.48 \mathrm{~cm}$, $16.73 \mathrm{~cm}$ and $167.90 \mathrm{~cm}$ ) and yield attributes like- number of flowers per plant (668.32 and 672.15), number of fruits per plant (258.94 and 272.51$)$, fruit yield per plant $(9.61 \mathrm{~kg}$ and $12.29 \mathrm{~kg}$ ) and fruit yield (48.04 t/ha and 61.45 t/ha) in both the years respectively (2017-18 and 2018-19) and also on the basis of mean data $(670.24,265.73,10.95 \mathrm{~kg}$ and $54.75 \mathrm{t} / \mathrm{ha})$ was obtained in case of $\left(\mathrm{F}_{2}\right) 80 \% \mathrm{RDF}$.

The lowest values of growth and yield characters were recorded in fertigation level $\mathrm{F}_{1}-60 \%$ RDF. It might be due to prolonged availability of nutrients during the growth, flowering and fruiting period from fertigation over basal application which might have improved the fruit set and retention. Similar results have also been reported by Shankar et al., (2002) in guava.

Among the various level of mulching, silver mulch $\left(\mathrm{M}_{2}\right)$ recorded maximum plant height $(138.95 \mathrm{~cm}$ and $143.71 \mathrm{~cm})$, plant girth (15.52 $\mathrm{cm}$ and $17.89 \mathrm{~cm})$ and plant spread (168.20 $\mathrm{cm}$ and $168.50 \mathrm{~cm}$ ) in both the years respectively (2017-18 and 2018-19) and also on the basis of mean data $(141.33 \mathrm{~cm}, 16.71$ $\mathrm{cm}$ and $168.35 \mathrm{~cm}$ ) and yield attributes likenumber of flowers per plant (635.23 and 641.25), number of fruits per plant (250.43 and 264.92), fruit yield per plant $(9.00 \mathrm{~kg}$ and $11.01 \mathrm{~kg}$ ) and fruit yield (45.00 t/ha and 55.05 $\mathrm{t} / \mathrm{ha}$ ) in both the years respectively (2017-18 and 2018-19) and also on the basis of mean data $(638.24,257.68,10.01 \mathrm{~kg}$ and 50.05 t/ha). The lowest values of growth and yield characters were recorded in mulch level $\mathrm{M}_{3}-$ Without mulch. 
Table.1 Effect of fertigation levels and different types of mulch on growth of guava (Psidium guajava L.)

\begin{tabular}{|c|c|c|c|c|c|c|c|c|c|}
\hline \multirow[b]{2}{*}{ Treatments } & \multicolumn{3}{|c|}{ Plant Height (cm) } & \multicolumn{3}{|c|}{ Plant girth (cm) } & \multicolumn{3}{|c|}{ Plant spread } \\
\hline & 2017-18 & 2018-19 & $\begin{array}{l}\text { Pooled } \\
\text { mean }\end{array}$ & 2017-18 & 2018-19 & $\begin{array}{l}\text { Pooled } \\
\text { mean }\end{array}$ & 2017-18 & 2018-19 & $\begin{array}{l}\text { Pooled } \\
\text { mean }\end{array}$ \\
\hline$\left(V_{1}\right)$ Lalit & 144.65 & 143.53 & 144.09 & 15.82 & 17.89 & 16.86 & 165.62 & 173.78 & 169.70 \\
\hline $\begin{array}{l}\left(V_{2}\right) \text { Allahabad } \\
\text { Safeda }\end{array}$ & 135.87 & 137.90 & 136.89 & 14.43 & 17.53 & 15.98 & 161.65 & 160.59 & 161.12 \\
\hline$\left(V_{3}\right)$ Sardar (L-49) & 135.35 & 136.11 & 135.73 & 12.95 & 15.80 & 14.38 & 156.79 & 164.34 & 160.57 \\
\hline CD at $5 \%$ & 3.56 & 5.87 & 4.72 & 1.02 & 1.31 & 1.17 & 7.89 & 3.84 & 5.87 \\
\hline$\left(F_{1}\right) 60 \%$ RDF & 130.87 & 131.05 & 130.96 & 12.85 & 14.98 & 13.92 & 153.49 & 164.25 & 158.87 \\
\hline$\left(\mathrm{F}_{2}\right) \mathbf{8 0 \%}$ RDF & 137.84 & 147.12 & 142.48 & 15.95 & 17.50 & 16.73 & 165.85 & 169.95 & 167.90 \\
\hline$\left(\mathrm{F}_{\mathbf{3}}\right) \mathbf{1 0 0 \%} \mathrm{RDF}$ & 137.84 & 142.78 & 140.31 & 13.62 & 15.90 & 14.76 & 164.44 & 164.59 & 164.52 \\
\hline CD at $5 \%$ & 2.87 & 5.26 & 4.07 & 2.87 & 0.98 & 1.31 & 7.16 & 2.16 & 4.66 \\
\hline$\left(M_{1}\right)$ Natural mulch & 135.58 & 132.35 & 133.97 & 14.23 & 16.12 & 15.18 & 159.42 & 164.88 & 162.15 \\
\hline$\left(\mathbf{M}_{2}\right)$ Silver mulch & 138.95 & 143.71 & 141.33 & 15.52 & 17.89 & 16.71 & 168.20 & 168.50 & 168.35 \\
\hline$\left(M_{3}\right)$ Without mulch & 127.53 & 138.07 & 132.80 & 13.58 & 16.49 & 15.04 & 156.43 & 165.35 & 160.89 \\
\hline CD at $5 \%$ & 2.87 & 6.23 & 4.55 & 2.87 & 0.98 & 1.29 & 9.46 & 2.16 & 5.81 \\
\hline
\end{tabular}


Table.2 Effect of fertigation levels and different types of mulch on yield attributes of guava (Psidium guajava L.)

\begin{tabular}{|c|c|c|c|c|c|c|c|c|c|c|c|c|}
\hline \multirow[b]{2}{*}{ Treatments } & \multicolumn{3}{|c|}{ Number of flowers per plant } & \multicolumn{3}{|c|}{ Number of fruits per plant } & \multicolumn{3}{|c|}{$\begin{array}{l}\text { Fruit yield per plant } \\
\text { (kg) }\end{array}$} & \multicolumn{3}{|c|}{$\begin{array}{c}\text { Yield } \\
\text { ( t/ha) }\end{array}$} \\
\hline & 2017-18 & 2018-19 & $\begin{array}{l}\text { Pooled } \\
\text { mean }\end{array}$ & 2017-18 & 2018-19 & $\begin{array}{l}\text { Pooled } \\
\text { mean }\end{array}$ & 2017-18 & 2018-19 & $\begin{array}{l}\text { Pooled } \\
\text { mean }\end{array}$ & 2017-18 & 2018-19 & $\begin{array}{l}\text { Pooled } \\
\text { mean }\end{array}$ \\
\hline$\left(\mathrm{V}_{1}\right)$ Lalit & 645.52 & 651.05 & 648.29 & 261.32 & 266.28 & 263.80 & 9.93 & 12.77 & 11.35 & 49.62 & 63.88 & 56.75 \\
\hline $\begin{array}{l}\left(V_{2}\right) \text { Allahabad } \\
\text { Safeda }\end{array}$ & 619.86 & 625.44 & 622.65 & 259.35 & 261.67 & 260.51 & 8.77 & 10.63 & 9.70 & 43.86 & 53.15 & 48.51 \\
\hline $\begin{array}{l}\left(V_{3}\right) \text { Sardar } \\
(L-49)\end{array}$ & 610.53 & 608.24 & 609.39 & 225.78 & 256.12 & 240.95 & 6.28 & 9.13 & 7.71 & 31.38 & 45.67 & 38.53 \\
\hline CD at $5 \%$ & 9.23 & 10.56 & 9.90 & 12.19 & 9.03 & 10.61 & 1.19 & 0.37 & 0.78 & 5.95 & 1.89 & 3.92 \\
\hline$\left(\mathrm{F}_{1}\right) 60 \% \mathrm{RDF}$ & 588.95 & 590.94 & 589.95 & 215.12 & 254.67 & 234.90 & 8.70 & 8.08 & 8.39 & 43.48 & 40.40 & 41.94 \\
\hline$\left(\mathrm{F}_{2}\right) \mathbf{8 0 \%} \mathrm{RDF}$ & 668.32 & 672.15 & 670.24 & 258.94 & 272.51 & 265.73 & 9.61 & 12.29 & 10.95 & 48.04 & 61.45 & 54.75 \\
\hline$\left(\mathrm{F}_{3}\right) \mathbf{1 0 0 \%} \mathrm{RDF}$ & 632.19 & 638.19 & 635.19 & 245.14 & 256.88 & 251.01 & 6.67 & 10.17 & 8.42 & 33.34 & 50.85 & 42.10 \\
\hline CD at $5 \%$ & 10.35 & 10.98 & 10.67 & 12.43 & 9.61 & 11.02 & 1.20 & 0.38 & 0.80 & 5.98 & 1.89 & 3.94 \\
\hline $\begin{array}{l}\left(\mathrm{M}_{1}\right) \text { Natural } \\
\text { mulch }\end{array}$ & 618.88 & 625.88 & 622.38 & 235.14 & 259.99 & 247.57 & 8.18 & 10.94 & 9.56 & 40.90 & 54.70 & 47.80 \\
\hline $\begin{array}{l}\left(\mathbf{M}_{2}\right) \text { Silver } \\
\text { mulch }\end{array}$ & 635.23 & 641.25 & 638.24 & 250.43 & 264.92 & 257.68 & 9.00 & 11.01 & 10.01 & 45.00 & 55.05 & 50.05 \\
\hline $\begin{array}{l}\left(\mathrm{M}_{3}\right) \text { Without } \\
\text { mulch }\end{array}$ & 608.58 & 620.45 & 614.52 & 201.43 & 259.15 & 230.29 & 7.79 & 10.58 & 9.19 & 38.95 & 52.90 & 45.92 \\
\hline CD at $5 \%$ & 8.56 & 7.79 & 8.18 & 9.58 & 9.09 & 9.34 & 0.99 & 0.37 & 0.68 & 5.12 & 1.89 & 3.51 \\
\hline
\end{tabular}



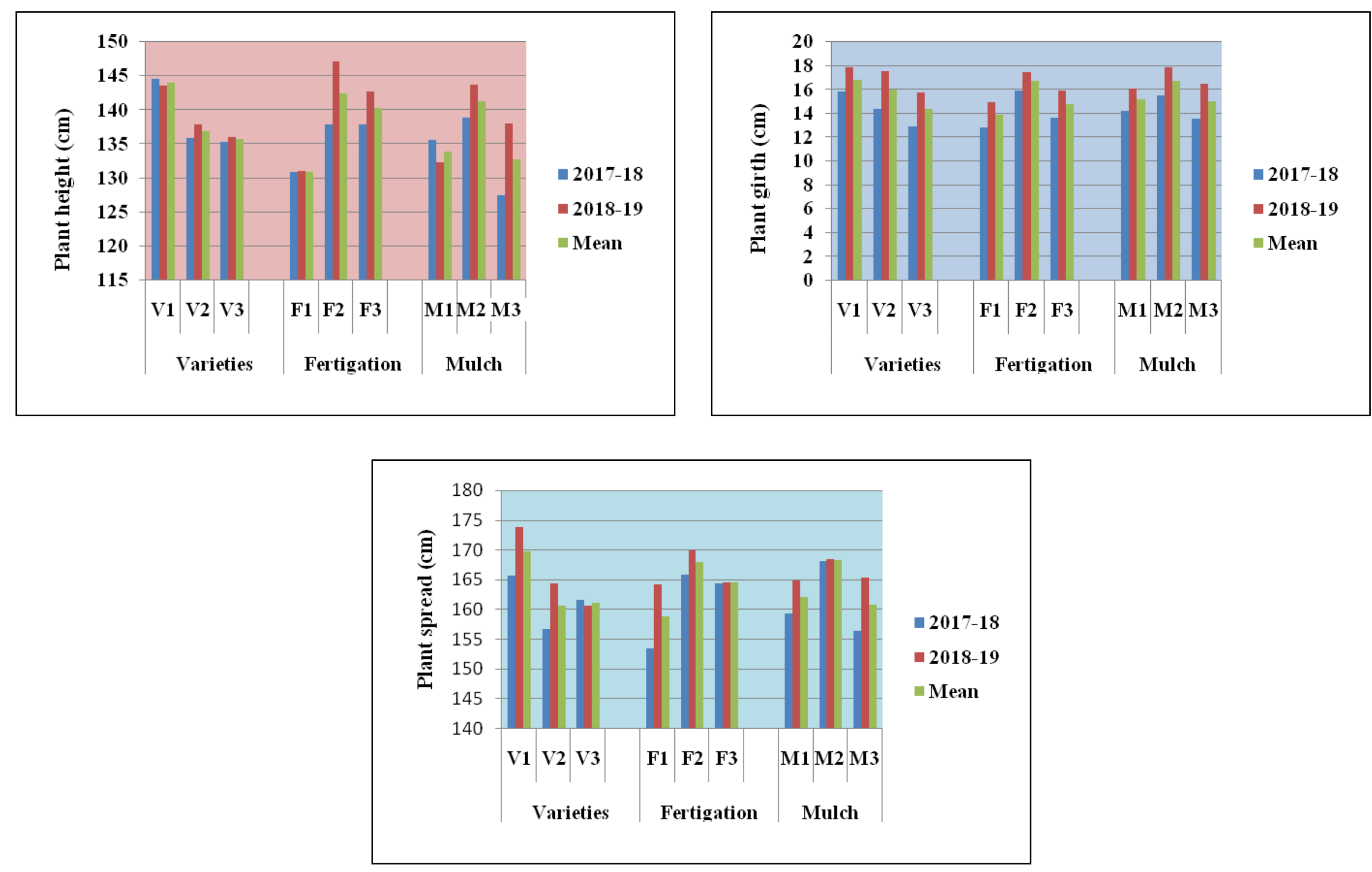

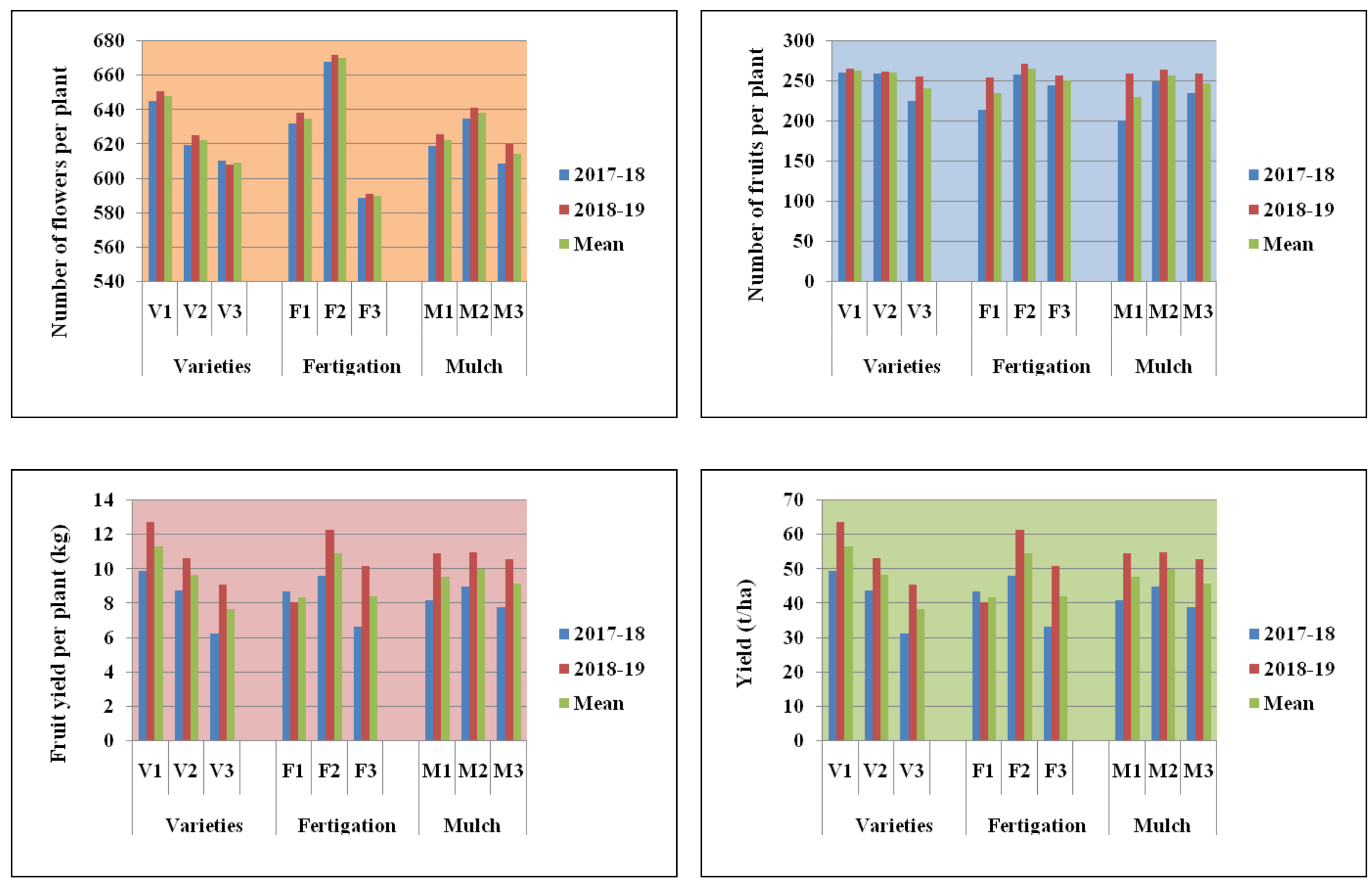
These results are in full conformity with the findings of Borthakur and Bhattacharyya (1998) in guava. Mulching treatments had been reported to increase phosphate uptake by crop, principally because it encouraged surface rooting of the crop, kept the surface soil moist for a longer time and avoided fixation of applied phosphorous leading to higher phosphate uptake from surface soil by surface rooting under mulches. Phosphorous being an essential constituent of biologically active macro - molecules ( nucleic acids, coenzyme NAD, NADP, ATP etc) is the integral part in important plant process like photosynthesis, glycolysis, respiration, fatty acid synthesis etc, contributing to the overall better performance of a plant. Hence the increased level of phosphorous uptake under mulched condition might have possibly increased the overall growth of fruit yield of guava plant.

\section{References}

Berad, S.M., Shinde, S.H. and Dahiwalker, S.D. 1998. Effects of drip fertigation and paired planting on productivity and economics of banana. J. Maharastra Agriculture University, 23(3): 288-290.

Borthakur, P. K. and Battacharyya, R. K. 1998. Effect of organic mulches on soil phosphorus, potassium and total yield on guava. Annals Agri. Bio. Res., 3: 223-26.

Deshmukh, M.M. and Sen, N.L. 2000. Studies on irrigation scheduling and point of application through drip irrigation to guava (Psidium guajava L.) variety Allahabad Safeda. Haryana J. Hort. Sci., 29(3/4): 156- 158.

Doorenbos, J. and Pruitt, W.O. 1977. Guidelines for predicting crop requirements. Irrigation and Drainage paper No. 24 (Revised) FAO, Rome.

Khan, J. N., Jain, A. K., Sharda, R., Singh, N.,
Gill, P. P. S., Kaur, S. 2013. Growth, yield and nutrient uptake of guava (Psidium guajava L.) affected by soil matric potential, fertigation and mulching under drip irrigation. Agricultural Engineering International: CIGR Journal. 15(3): 17.

Kumar, A., Singh, R.K., Sinha, A.K., Singh, H.K. and Mishra, A.P. 2007. Effect of fertigation on banana through drip irrigation in North Bihar. J. Res. Birsa Agric. Univ., 19: 81-86.

Paikra, P. S., Sahu, G. D. and Dikshit, S.N. 2016. Effect of fertigation scheduling and mulching technique in three cultivars of guava (Psidium guajava $\mathrm{L}$.) under ultra high density planting in Chhattisgarh. Trends in Biosciences 9(10): 573-577.

Panse, V.G. and Sukhatme, 1985. Statistical methods for agricultural workers. ICAR, New Delhi.

Shankar, U., Pathak, R.A., Pathak, R.K.and Ojha, C.M. 2002. Effects of NPK on the yield and fruit quality of guava cv. Sardar. Progr. Hort. 34: 49-55.

Sharma, S., Halder, A., Patra, S K., and Ray, R. 2012. Effect of drip irrigation and nitrogen fertigation on water use efficiency (WUE) and cost economics of guava cv. Khaja. Progressive Hort., 44 (1): 134-139.

Shukla, A.K., Pathak, R.K., Tiwari, R.P. and Nath, V. 2001. Influence of irrigation and mulching on plant growth and leaf nutrient status of aonla (Emblica officinalis G.) under sodic soil. J. Appl. Hort., 2: 37-38.

Singh, R.M., Bhandarkar, D.M., Singh, D.K., Reddy, K.S., Rao, K.V.R., and Mathankar, S.K., 2012. Technoeconomic feasibility of drip fertigation in guava (Psidium guajava L.). Kolkata, India: MKK Publication, Environment and Ecology. 30 (2): 271-274. 


\section{How to cite this article:}

Purnendra Kumar Sahu, G. D. Sahu and Vedhika Sahu. 2020. Impact of Fertigation Levels and Different Types of Mulching on Growth and Yield of Guava (Psidium Guajava L.) under Ultra-High Density Planting in Chhattisgarh Plains. Int.J.Curr.Microbiol.App.Sci. 9(05): 10341042. doi: https://doi.org/10.20546/ijcmas.2020.905.113 